\title{
Analysis of the relation of logistics service level and the shopping experience in brazilian e-commerce: a rating scale
}

\section{Gisela Demo}

giselademo@gmail.com

Universidade de Brasília (UnB), Brasília, Distrito Federal, Brasil

Patrícia Guarnieri profpatriciaunb@gmail.com Universidade de Brasília (UnB), Brasília Distrito Federal, Brasil

\section{Beatriz Alvarenga}

beatriz.alvarenga@gmail.com Distrito Federal, Brasil

\author{
ABSTRACT
}

The performance of logistics becomes even more relevant in e-commerce, demanding high specialization. Considering the lack of instruments in the literature to assess the logistics system related to online shopping experience, the objective of this quantitative research was to develop and validate a rating scale of e-commerce. The results constitute a preliminary diagnosis that can support managers of electronic commerce to take better decisions related to logistics service level. It is important, considering that this type of decisions usually involves high amounts of money and not always the investments in logistics are perceived by customers. Besides, the rating scale of e-commerce considering logistics aspects, developed and validated in this research, can aid managers to design strategies and to take decisions that optimize the logistics activities and the shopping experience in e-commerce.

KEYWORDS: E-commerce. Logistics Service Level. Online Shopping Experience.

Rating scale.
\end{abstract}




\section{INTRODUCTION}

Increasingly, the search for efficiency and effectiveness in meeting the needs of consumers is a prerequisite to high quality of traded goods and services provided to the end customer (BALLOU, 2001; CHRISTOPHER, 2001; HARRISON; VAN HOEK, 2003).

It is important to point out that the purpose of enterprise logistics is to meet customer requirements, with a low cost and efficiency. However, it is important consider the raising awareness of those who receive the service or product: the customers. So, companies need, continuously, to adapt the logistics management as customer needs (COUNCIL OF SUPPLY CHAIN MANAGEMENT PROFESSIONALS - CSCMP, 2010; CHRISTOPHER, 2001).

Nevertheless, in order to meet all these objectives fully, companies must be a high level of integration and coordination between the logistics processes and activities, ensuring an adequate service level. Thus, more and more, the logistics management is aimed to the acquisition of greater efficiency related to the flow of products. This efficiency should flow continuously to guarantee customer satisfaction through the logistics processes in an integrated manner (LANKFORD, 2004).

The market is experiencing a period of intense competition and rapid change, mainly related to the customer service and cost reduction (Hoff et al., 2010). Production processes increasingly dynamic, diversified communication channels, delivering value to the customer and the increasing diversification of products and services are just a few factors that illustrate this scenario. From this context, organizations that use effectively and efficiently its logistics system, can achieve a sustainable competitive advantage over your competition, thus obtaining the preference of its consumers (GUARNIERI; HATAKEYAMA, 2010). This goal coincides with the great goal of marketing, which is to improve the customer shopping experience to build customer loyalty (DEMO, 2014).

Also, it is important to emphasize that Brazil had a third of all online consumers across Latin America in 2015. This fact should remain until 2019, when Brazil should reach 49.7 million online consumers and $U \$ 84.75$ billion in sales throughout the region (E-MARKETER, 2016). Thus, the level of logistics service shall accompany the growth of online consumption.

A subject in the area of administration, an essentially practical science, must offer academic and practical contributions that justify its relevance. Considering the relevance of logistics issues in shopping experience for organizations today, there are certain gaps in literature, which can be pointed out. In the academic perspective, there are few quantitative studies in the field of logistics, focusing on the consumer perspective. Moreover, most of the literature brings case studies, without induction of new theories. Particularly it was not found papers including scales validation studies to assess the shopping experience in electronic commerce (e-commerce), neither addressing the issue of the logistics service level in shopping experience, which is considered a vital aspect. Qian (2016) emphasizes that evaluate e-commerce logistics service quality research has not yet formed a complete and scientific theoretical system and method.

As to managerial implications, given the lack of scales assessing the ecommerce, the study is also contributory to the extent that performs a diagnosis 
to support decision making of managers towards improving logistics service level. Consequently, it is expected that through the improvement of logistics service level, the shopping experience in virtual business would improve as well. Still, it is worth remembering that the scale proposed in this study can be used by any company that has its operations on the Internet.

Additionally, the constructs measures translate the perceptions that people have of organizational actions. Besides, it is important to emphasize that only knowing such perceptions and evaluating them through scientific instruments, that is scales, the organizations will know their effectiveness (DEMO et al., 2012). Thus, the objective of this research is to develop and validate scientifically, a scale to measure consumer perceptions with respect to their online shopping considering aspects related to logistics service level.

The remain of this article is structured as follows: Section 2 presents the literature review on logistics operations and service level, e-commerce logistics, shopping experience in e-commerce. Besides, this section presents some recent empirical researches on e-commerce and logistics. The section 3 describes the methods used in order to develop and assess a rating scale for e-commerce considering logistics aspects. The section 4 presents the results and the discussion. Finally, the section 5 presents the concluding remarks, limitations and suggestions for future studies.

\section{THEORETICAL BACKGROUND}

\section{LOGISTICS OPERATIONS AND SERVICE LEVEL}

Organizations are seeking business prosperity, optimizing its processes and aiming continuous improvement to better compete in the market. In this scenario, the logistics gains special meaning, encompassing aspects such as the availability of the product on the market at a low cost (HARRISON; VAN HOEK, 2003). The mission of logistics is delivering the proper product or service, at the right place and time and, in the desired conditions, while providing the greatest contribution to the company (BALLOU, 2001).

Then, the company should, in addition to perform all activities according to the mission of logistics, satisfy their customers through good buying experience. In addition, logistics is seen as a process, which means that it includes all the important activities for the provision of goods and services to consumers effectively (BALLOU, 2001; CHRISTOPHER, 2001). Furthermore, it is observed that companies that have a higher level of logistics integration are those using more information systems, an essential factor for companies operating in ecommerce (RUTNER; GIBSON; WILLIAMS, 2003).

According to Ching (2010), in order to perform its function regarding customer value, it is necessary that the company perform repositioning actions that drive its structure for the same common goal of integrated and collaborative manner. Additionally, logistics structure is divided into three areas, the first is supply logistics, the second is production logistics, the third is distribution logistics. More recently, it is recognized that there is a fourth area: reverse logistics (COHEN; ROUSSEL, 2004; COUNCIL OF SUPPLY CHAIN MANAGEMENT PROFESSIONALS CSCMP, 2011). The logistical subareas and its duties are shown in Chart 1. 
Chart 1- Logistics operations/activities

\begin{tabular}{|c|c|c|c|c|}
\hline Operations & $\begin{array}{l}\text { Supply } \\
\text { logistics }\end{array}$ & $\begin{array}{l}\text { Production } \\
\text { logistics }\end{array}$ & $\begin{array}{l}\text { Distribution } \\
\text { logistics }\end{array}$ & Reverse logistics \\
\hline Phisical & $\begin{array}{l}\text { - Preparation of flow } \\
\text { to the production line } \\
\text { - Packaging } \\
\text { - Direct or indirect } \\
\text { deliver to production } \\
\text { line } \\
\text { - Premanufacturing } \\
\text { - Reception }\end{array}$ & $\begin{array}{l}\text { - Flow between } \\
\text { sectors } \\
\text { - Preparation of } \\
\text { delivery to the } \\
\text { warehouse or to } \\
\text { the client } \\
\text { - Packaging } \\
\text { - Delivery }\end{array}$ & $\begin{array}{l}\text { - Organization of } \\
\text { warehouse } \\
\text { - Order settlement } \\
\text { - Packaging } \\
\text {-Initial } \\
\text { transportation } \\
\text {-Final transportation } \\
\text {-Post-manufacturing }\end{array}$ & $\begin{array}{l}\text { - Installation } \\
\text {-Preparation of } \\
\text { reposition parts } \\
\text { order } \\
\text { - Packaging } \\
\text { - Delivery } \\
\text { - Requesting/tests } \\
\text { - Refurbishing } \\
\text { - Repair sending } \\
\text { - Inspection } \\
\text { - Destruction }\end{array}$ \\
\hline Information & \multicolumn{2}{|c|}{$\begin{array}{l}\text { - Data delivery } \\
\text { - Updating, database } \\
\text { - Products packaging, } \\
\text { - Clients base } \\
\text { - Delivery location, } \\
\text { - Input of order data, } \\
\text { - Input of stocks (entrance and exit), }\end{array}$} & \multicolumn{2}{|c|}{$\begin{array}{l}\text { - Monitoring of operations of pre and post } \\
\text { manufacturing, } \\
\text { - Delivery documents, } \\
\text { - Input of data of service level, } \\
\text { - Service level monitoring, } \\
\text { - Critical indicators information. }\end{array}$} \\
\hline $\begin{array}{l}\text { Planning and } \\
\text { management }\end{array}$ & - Purchasing planning & $\begin{array}{l}\text {-Production plant } \\
\text { planning } \\
\text {-Orders supplying }\end{array}$ & $\begin{array}{l}\text { - Forecast } \\
\text {-Orders monitoring } \\
\text {-Transportation } \\
\text { cycle and delivery } \\
\text { - Orders supplying }\end{array}$ & $\begin{array}{l}\text { - Forecast } \\
\text { - Monitoring of } \\
\text { orders of } \\
\text { reposition parts } \\
\text { - Delivery planning } \\
\text { - Orders supplying }\end{array}$ \\
\hline
\end{tabular}

Source: Adapted from Dornier et al. (2007, p. 49).

As noted in Table 1 all activities involved in subareas of logistics affect the quality of the delivery of product or service to clients. The need of the interconnection through information, combining the databases, documents and monitoring of the operations, can add value to logistics activities. Chopra and Meindl (2007) highlight the links in the supply chain as: customers, retailers, wholesalers, distributors, manufacturers and suppliers of parts or raw materials, which can be integrated in order to ensure the satisfaction of the end customer.

These subareas directly impact the scope of inventory reduction goals, the time of supply, costs, quality control, and the availability of materials at the right time and the right place, thus enabling an efficient and effective flow of materials, products and services along the supply chain (LAMBERT; COOPER, 2000; COOPER; ELLRAM, 1993). In addition, Ballou (2006) highlights that linking sales' response to various logistics customer' service is a research priority. First of all because logistics customer' service is the performance of the processes associated with providing a product or service to customers, such as order processing time; order fill rate, and delivery time. Besides, it is also multidimensional, because it depends on the product or service, their locations, competitive setting, and their particular service needs. It can also be said that customer' service is a basis for customer' satisfaction.

Although it is difficult to measure accurately the response of the customers to service level, the firm's revenue generation can be considered as a response, 
which can result in customer patronage, market share, and customer loyalty (BALLOU, 2006). This issue becomes even more important when we consider that Internet has redefined information sharing boundaries and the way to sale the products, opening new forms for managing logistics services (RABINOVICH; KNEMEYER; MAYER, 2007).

Furthermore, with continued growth of e-commerce, the importance of logistics services is set to increase (RAMANATHAN, 2010).Actually, the ultimate success of an e-commerce initiative is strictly dependent on the effectiveness of the distribution process (GIUFFRIDA et al., 2016). Meidutè-Kavaliauskiené, Aranskis, and Litvinenko (2014) states that presently, logistics service companies should know their customers because the company, having sufficient information and knowledge about its customers, has more opportunities to make right decisions on the development of new services that provide real value to customers as well as to assess quantitatively the values desired by customers.

\section{E-COMMERCE LOGISTICS}

With the globalization process, many industries began to confront a reality of competition on a global scale. From the perspective of the production management, one of the consequences of this process was the considerable review of competitive priorities.

In this context, some dimensions in which organizations have greater concern in competitive advantage were considered, such as cost, quality, delivery performance and flexibility. In terms of trend, it is possible to observe a situation where the customer wants, increasingly, customized products with reliable delivery times and the prompt delivery (PIRES, 2004). In fact, customers consider several factors to judge the performance of a company and decide on their loyalty. The logistics operation factors are directly related to this performance measurement (RAMANATHAN, 2010).

Moreover, the logistics need to be flexible in the short term to provide operational and flexible long-term opportunities to suit the new positioning of the marketing channel (ALDIN; STAHRE, 2003).

A key result of globalization and the consequent technological advancement is selling on e-commerce, also known as electronic commerce (e-commerce). It is important to point out that electronic commerce includes all interactions between companies and consumers that can be made using the Internet or other means of data communication (MEIRA JR., 2002). In the mid-nineties, with the popularization of internet trading, e-commerce acquired its most popular forms, business to business (B2B), business to consumer (B2C) and consumer-toconsumer (C2C). Evidently, the use of e-commerce has become very common following the spread of IT systems such as laptops, tablets and smartphones (MORGANTI et al., 2014).

The B2B e-commerce logistics problem (ELP) is well explored in literature and involves, in general: setting logistics service prices, determining transportation and inventory decisions, integrating B2B e-commerce and logistics trading, as well as utilizing common protocols and shared logistics assets to improve profitability and market efficiency (XU; CHENG; HUANG, 2015).It is important to point out that the spread of online shopping has generated significant demand 
for dedicated delivery services to the end consumer, mainly in the case of physical goods (MORGANTI et al., 2014).

As a consequence of the growth of the Internet usage and online shopping, the freight distribution in urban areas was transformed (DE MARCO et al., 2014). Nevertheless, data on the volume and frequency of online shopping for physical goods is deficient, which affects future researches on city logistics for ecommerce (MORGANTI et al., 2014). Rabinovich, Knemeyer and Mayer (2007) emphasize that organizations that market products over the Web have increasingly share market demand data with other firms, such as logistics service provider, in order to enrich the order fulfillment services. Furthermore, studies related to $\mathrm{B} 2 \mathrm{~B}$ e-commerce logistics lay emphasis on the integrated logistics chains, in which long-term relationships between B2B e-commerce and thirdparty logistics providers (3PLs) afford the optimization of logistics (XU; CHENG; HUANG, 2015).

According to ABComm (2016) (Brazilian Association of Electronic Commerce), there are 13.5 thousand active virtual stores in Brazil Internet sales totaled U\$S 9,87 billion in 2014 , up $27 \%$ over the previous year. As a result of this dramatic increase in the volume of transactions through e-commerce, which is often disordered, the number of exchanges and product returns also suffered great impact. We can cite as main impact of the e-commerce and associated technologies, the automation of common processes, such as distribution, sales, after-sales service and inventory management (SAVRUL; INCEKARA; SENER, 2014).

In the last decade, e-commerce has been one of the biggest drivers of evolution in logistics (XU; CHENG; HUANG, 2015). Thus, the recent growth of global trade and the introduction of e-commerce logistics operations expanded in size and complexity (BOWERSOX; CLOSS, 2006). The widespread development of e-commerce in recent years suggests that companies require a significant competitive advantage to attract and retain consumers through logistics system. Especially considering that since there is no physical contact with the consumer, perceived value lies in the proper execution of logistics activities that support the business process (BOWERSOX; CLOSS, 2006). In addition, the modern logistics have improved the efficiency of material flow, reduce distribution costs, and, at the same time, the recent development of e-commerce also contributed to the expansion of the logistics market (Yu et al., 2016)

It is speculated that the internet will open a new world of relationships between companies and their consumers because it offers potentially a new direct channel of contact of consumers with businesses (BOWERSOX; CLOSS; COOPER, 2006). Still, according to Kotler and Keller (2006), the Internet offers businesses and consumers opportunities for greater interaction and personalization. Previously, product offerings or services were sent to consumers by marketing standards means (magazines, bulletins, newsletters or ads), today companies can send individualized content to the consumer and so the companies spend to interact and dialogue with a much larger group than the past.

Thus, there are new ways of sales and more responsive relationships with end customers. The application of online purchases has considerable potential to streamline processes, errors reduction, lower costs and ultimately, customer 
loyalty (KOTLER; KELLER, 2006). It is important to emphasize that the revolution in information substantially change the landscape of the marketing and realigned the target number of participants in the value delivery process to the customer (QIAN, 2016).

Additionally, it is important to highlight that in Latin America, e-commerce has grown from US\$1.6 billion to US\$ 43 billion in the past decade, with Brazil accounting for $59 \%$ of the Latin American market (SAVRUL; INCEKARA; SENER, 2014). A survey released by the Brazilian Association of Electronic Commerce (ABComm) (2016) showed that internet via sales totaled US\$9.87 billion in 2014. Also in 2012, nine million Brazilians held the first online purchase and Brazilian universe with access to the World Wide Web has reached 68 million. In 2015, Brazil had a third of all online consumers across Latin America. This fact should remain until 2019, when Brazil should reach 49.7 million online consumers and US\$ 84.75 billion in sales throughout the region (E-MARKETER, 2016).

In the B2C (business-to-consumer market, or consumer market) ecommerce, logistics managers are being forced to implement different operating practices in order to meet new demand formats consumers. Besides, demand levels in e-commerce have been extremely difficult to predict. These situations lead to inefficient logistics response, with delays in deliveries, excess suspended requests, customer complaints and image damaged company (NOVAES, 2007).

\section{SHOPPING EXPERIENCE IN E-COMMERCE}

It is necessary to point out how the shopping experience occurs in the context of electronic commerce. According to Kotler and Keller (2006), the latest form of interactive marketing is the electronic channels. So, there is a new form of customer interaction and business, where the customer initiates and controls the process. In this configuration, the customers define what information they need, where offers are interested and what price they are willing to pay, especially considering the ease of comparing prices on the Internet.

Therefore, it is necessary for companies that sell their products through ecommerce have a site to attract, at first sight, consumers and be interesting enough to encourage new visitors. So, to stimulate new business, companies need to pay special attention to the context (physical arrangement or layout and industrial or design drawing) and content (text, images, sound and video) of the site, since visitors judge the performance of virtual enterprise based on its ease of use and physical attractiveness that enhances your shopping experience (KOTLER; KELLER, 2006).

Morganti et al. (2014) emphasize that deliveries, returns and way of payment are the main factor that influences the customer's experience in online shopping. Meidutè-Kavaliauskienè, Aranskis, and Litvinenko (2014) highlight that some factors influencing shopping experience may be controlled by a company, foreseen and be prepared for, however other factors depend on the psychological, cultural and social influences of the customers. Thus, logistics companies face a great challenge to understand their customer, find out his needs and strive to meet customer expectations.

It can be perceived that the expectations of consumers in e-commerce tend to be more challenging than the traditional business transactions. These 
requirements and additional demands have required significant changes in the dynamics of the operation of online businesses, as well as new solutions for the satisfaction of clients. In this context, as Ramanathan (2010) states, logistics plays a very important role in ensuring customer loyalty. As main factors related to logistics experienced by customers after making payments, the physical delivery and reliability can be pointed out as very important, and classified as postpurchase factors.

Nevertheless, as a result of high growth in e-commerce, it can be observed several logistical failures culminating in errors and problems, thus affecting the relationship with the consumer, who often had their expectations dashed to receive the product. Morganti et al. (2014) point out some logistics problems experienced by customers in online shopping in Europe, more specifically, in France and Germany. Most of these problems are related to deliveries, such as: delivery at home when nobody was there; delay in delivery; delivery costs too high; the lack of tracking delivery status; the need to collect the product from a distant collection point, and damaged goods.

On the other hand, as main benefits of e-commerce, Savrul, Incekara and Sener (2014) highlighted: remove physical limitations of time and space; reduce delivery costs; minimize transport obstacles; speed communication between buyer and seller; reduce cost in advertisement and promotion, and save transaction costs. In addition, Ramanathan (2010) pointed out several factors that contribute to a positive shopping experience in e-commerce can be highlighted: convenience; product availability; returns policy; among others, which are directly dependent on the performance of the logistics systems of the company.

In this scenario, there are significant logistical challenges in the practice of ecommerce by businesses. Logistics is largely influenced by decisions from marketing and thus, there is a need of cooperation between these areas (ALDI; STAHRE, 2003). Rutner, Gibson and Williams (2003) states that many ecommerce businesses fail to fulfill the promises made to online consumers by marketing due to inadequate logistical support. On the other hand, companies that join the planning of logistics subsystems with e-commerce are successful. Ramanathan (2010) found that the impact of logistics performance on overall performance is stronger for more efficient e-commerce firms than for less efficient ones. Therefore, the efficient firms are able to convert their logistics performance into customer loyalty more favorably. Qian (2016) points out as indicators of logistics in e-commerce quality order timeliness response, order release cycle, answer response rate, agreed delivery time, error processing speed and economy related to costs of logistics. Burma (2015), in turn, emphasizes the positive relation between logistic structure and e-commerce and the importance of the logistic performance index to measure the quality of logistics service in ecommerce.

\section{EMPIRICAL RESEARCHES ON E-COMMERCE AND LOGISTICS}

In the literature, several researches have recently studied and described the influence of logistics in e-commerce; some of them should be detached: Rabinovich and Knemeyer (2006) found that Internet sellers establish relationships with logistics service providers in order to extract value from the 
providers' network of logistical resources; to lower the costs and, better fill their customers' orders. Posteriorly, Rabinovich, Knemeyer and Mayer (2007) studied conceptually and empirically why Internet commerce firms have established relationships with providers of logistics services in outbound distribution channels. The authors found that, based on Transaction Costs Theory, low levels of asset specificity and uncertainty these relationships.

Heim and Field (2007) studied the process drivers of specific e-commerce assessment factors, such as: payment process, on-time delivery, ease of returns and refunds, privacy experience and customer support. Cho et al. (2008) assessed the importance of logistics capability on firm performance of consumer electronics industry. Ramanathan (2010) studied the relationship between logistics performance and customer loyalty in the context of the business toconsumer (B2C) segment of electronic commerce. They found that the impact of logistics performance on the overall performance does not change with the risk characteristics (price and ambiguity) of products. Xianglian and Hua (2013) analyze the characteristics and mode of e-commerce logistics, combined with the current situation and existing problems of e-commerce logistics in China.

Morganti et al. (2014) compared the alternatives to home delivery that have been developed by French and German parcel delivery operators which developed pick-up points in stores and automated lockers networks. The paper includes an analysis of the key drivers of these services with reference to the strategies of service providers and e-commerce firms as well as consumer preferences. Meidutè-Kavaliauskienè, Aranskis, and Litvinenko (2014) analysed the concept of customer satisfaction and the understanding of service quality, specifically aiming at logistics service companies.

$\mathrm{Xu}$, Cheng, and Huang (2015) propose an efficient intermodal transportation auction that incorporate both intermodal service costs and transaction costs for the B2B e-commerce logistics problem (ELP). Burma (2015) studied the relations among population size, e-commerce sales penetration, income and logistic performance. Also, he identified which factor(s) should be prioritized by countries to increase their e-commerce.

Yu et al. (2016) summarize in their study the logistics models and supporting techniques for the e-commerce and highlights the challenges, opportunities, and future perspectives. Likewise, Zhang et al. (2017) propose a framework to solve the e-commerce transportation service trading problem in B2B e-commerce. This problem involves the optimization of the matching issue between the sets of online orders generated by the e-commerce platform and the sets of transport vehicles supplied by logistics service providers.

Han and Wang (2017) state that there are several conditions and opportunities for the development of the e-commerce, however there are bottlenecks for the development of logistics. In order to solve this problem, the authors propose the e-commerce logistic distribution model based on the intelligent community property, which can reduce logistics costs and improve customer satisfaction. 


\section{METHODS}

This research can be described as instrumental, descriptive (survey), crosssectional and quantitative.

In order to develop the items of the scale, eighteen people who make purchases via e-commerce were interviewed. The interviews lasted about 10 minutes and were recorded and transcribed. The questions elaborated upon the literature review on logistics and e-commerce were:

1) Considering, their purchases online, what features you consider essential in each of the logistics subareas to improve your shopping experience?

2) What factors are important/what sites need to have so that you have a good shopping experience online?

According to Demo et al. (2012), the content analysis of the interviews is necessary for the definition of the themes and categories that will support the development of the scale items.

Next, the theoretical analysis of the items was held, including both semantic and judge analysis (KERLINGER; LEE, 2008). The semantic analysis asks participants to verify the clarity of items of the scale and also either the existence of redundant items or the lack of an item fundamental to the construct. The sample for the semantic analysis consisted of 21 students of the course of Business from University of Brasilia, Brazil. Simultaneously, the judges' analysis was performed to examine whether the proposed items originated from the semantic analysis were appropriated to describe e-commerce from logistic service and online shopping experience. The sample for analysis judges was composed of 6 professionals and researchers of logistics area.

After the content, semantic and judges analyzes for the scale development, a questionnaire with 31 items was ready for application. The 31 items were randomized in order to avoid bias (KERLINGER; LEE (2008). The target population for the scale validation covered users of e-commerce residents in the city of Brasilia. The sample was restricted to individual subjects and was limited by internet access, as the research tool was applied online, through the TypeForm platform. As the target population tends to infinity, it was possible to use nonprobabilistic convenience sample (Cochran, 2007). Then, it was obtained 310 questionnaires in return.

Data were examined and the assumptions for multivariate analysis were checked, following the procedures recommended by Tabachnick and Fidell (2013) and Hair et al. (2009). Data was found to be very precise, with no registration errors or discrepancies in average and standard deviation measures. Also, there wasn't any case of multicollinearity or singularity as tolerance values were above 0.1 and variance inflation factor (VIF) values were less than 5.0(MYERS,1990; MENARD, 2002).

Missing data treatment was performed using the "listwise" method because according to Hair et al. (2009) and Tabachnick and Fidell (2013) is the most recommended treatment to remove the sample subjects who left a blank item. Thus, 19 respondents left a blank item and were excluded from the sample.

In sequence, analyses of outliers, normality and linearity were conducted as well and 41 individuals from the original sample (310) were deleted by using the 
Mahalanobis distance criterion ( $D 2=61.098 ; p<0.001$ ). The percentage of missing data was lower than $5 \%$ that is 19 respondents that were excluded by the Listwise Deletion method (TABACHNICK; FIDELL, 2013; HAIR et al., 2009).

The final sample counted then with 250 participants, still enough to run the purposed analysis, which according to Pasquali (2010), Field (2009) and Hair et al. (2009) may be considered a satisfactory sample for factorial analysis, since the authors suggest between 5 and 10 subjects per item of the instrument and the scale application version included 31 items. Finally, regarding sample characterization, women make up the majority of the sample, representing $54 \%$ of the total, $63 \%$ of the subjects were between 18 and 24 years of age and $56 \%$ have incomplete higher education. The frequency of purchase in the online medium, of the respondents was mostly monthly.

\section{RESULTS: PROPOSAL AND VALIDATION OF A RATING SCALE IN E-COMIMERCE}

The application version of the e-commerce rating scale was developed from the results of the categorical thematic content analysis proposed by Bardin (2011). Such analysis pointed out topics as deadline, physical integrity of the product upon delivery, reliability, access to products from other regions and countries, clear definition concerning product return and disposal procedures, product availability in stock, lower prices, conformity of products with quality and safety standards (e.g., ISO 9000) and feedstock quality. Those topics converged to a category named logistics system.

Another category called Shopping Experience comprises topics such as online communication tools for questions, complaints and suggestions, ease of site navigation, site layout, tool to access the opinions of other consumers of the product, various payment options, site security for customers' personal information and bank details, experimental tools/online tests of the products, possibility to track order status, ease of registering on the website, ease of order canceling, online promotional actions and site customization.

The existence of those two categories ratifies the relevance of such factors for the e-commerce, as suggested in the literature visited, what provides content validity for the scale.

Next, both semantic and judge analysis were performed. Those analyze produce the previous version of the scale, which included 31 items and was applied to the sample required.

Regarding the results of the validation of the scale, we used the principal component analysis and exploratory factorial analysis. Field (2009) and Hair et al. (2009) state exploratory factor analysis aims to determine whether the measured variables have correlation and are part of a larger, called factor.

In the first instance, the principal component analysis was performed to verify the possibility of using factorial analysis, as well as for the number of dimensions or factors. This analysis considers the total variance and seeks the maximum of variance explained by the linear combination of variables (PASQUALI, 2012). The first step in performing the setting of the number of factors second Pasquali (2012), is to verify whether variances or covariance present these are independent, i.e., check whether they have factorability. Thus, 
the calculation was performed through Kayser-Meyer-Olkin index (KMO), i.e. a test working with partial correlations of the variables analyzed. The value obtained in this test was 0.855 , which according to Kaiser (1974) is deemed worthwhile.

In order to define the number of factors, it was used the minimal factor loading of 0.32 as Pasquali (2012) recommends. The procedure used was Promax, an oblique rotation since it is expected correlation between the items, which is typical in the behavioral sciences. For the extraction of the data, the criterion used was the Guttman-Kaiser, the total of the Catell scree test, the explained variance and the parallel analysis (FIELD, 2009; HAIR ET AL., 2009).

In the first test, Kaiser-Guttman, the necessary information has been obtained by testing eingenvalues, which is the sum of column factor loadings squared to a factor. According to Pasquali (2012), the eigenvalues must be greater than 1, i.e., a factor should explain at least the amount of variance is accounted for by a single variable. So, the first test pointed to the possibility of up to 2 factors.

The Catellscree test consists of eigenvalues of chart analysis, the slope chart. According to Pasquali (2012), the test checks that point of the curve values pass a steep slope to a horizontal slope. Factors that are right to the point are not relevant and are called line of random noise. Factors left the point in question indicate the number to be used. Hence, the evaluation indicated that the number of factors would be between one and two.

The third test conducted, was the analysis of the total variance explained. When analyzed by a factor, the variance explained overall has the value of $26.378 \%$. As for two-factor has the value of $34.934 \%$. For three factors, the figure rises to $40.791 \%$. For four factors, the value is $45.587 \%$. It is noted that the above three factors, the gain total explained variance is not as large, which suggests the existence of three factors.

Table 1- Psychometric indices of the e-commerce rating scale

\begin{tabular}{|c|c|c|c|c|}
\hline Item & Variable & Weight & $\begin{array}{l}\text { Quality/ } \\
\text { Validity }\end{array}$ & $\begin{array}{l}\text { Commo } \\
\text {-nality }\end{array}$ \\
\hline Q.6 & $\begin{array}{l}\text { Clarity on product return } \\
\text { procedures }\end{array}$ & .66 & Very good & 623 \\
\hline Q.9 & $\begin{array}{l}\text { Online communication tools for } \\
\text { questions, complaints and } \\
\text { suggestions }\end{array}$ & .62 & Good & 465 \\
\hline Q.30 & Ease of cancel the order & .60 & Good & 600 \\
\hline Q.25 & Loyalty programs/frequency & .60 & Good & 622 \\
\hline Q.28 & $\begin{array}{l}\text { Ease of cancel the registration on } \\
\text { the website }\end{array}$ & .60 & Good & 546 \\
\hline Q.23 & $\begin{array}{l}\text { Ability to track /monitor the status } \\
\text { of the order }\end{array}$ & .59 & Good & 477 \\
\hline Q.16 & $\begin{array}{l}\text { Site security related to personal } \\
\text { information of customer } \\
\text { (guarantee that the data will not } \\
\text { be used by third parties) }\end{array}$ & .59 & Good & 755 \\
\hline
\end{tabular}




\begin{tabular}{|c|c|c|c|c|}
\hline Q.20 & $\begin{array}{l}\text { Reliability/quality of the raw } \\
\text { material of the product }\end{array}$ & .58 & $\overline{\text { Good }}$ & 426 \\
\hline Q.19 & $\begin{array}{l}\text { Company with sustainability } \\
\text { actions (environmental and social } \\
\text { programs) }\end{array}$ & .58 & Good & 513 \\
\hline Q.7 & $\begin{array}{l}\text { Clarity in discard procedures after } \\
\text { use of products and materials, } \\
\text { when necessary }\end{array}$ & .53 & Reasonable & 496 \\
\hline Q.10 & User-friendliness on website & .53 & Reasonable & 537 \\
\hline Q.18 & $\begin{array}{l}\text { Product compliance with quality } \\
\text { and safety standards (quality } \\
\text { standards, minimum age for toys) }\end{array}$ & .53 & Reasonable & 529 \\
\hline Q.17 & $\begin{array}{l}\text { Site security related to bank } \\
\text { details }\end{array}$ & .52 & Reasonable & 757 \\
\hline Q.13 & $\begin{array}{l}\text { Prices comparison tool with } \\
\text { competing products } \text { or physical } \\
\text { stores }\end{array}$ & .51 & Reasonable & 365 \\
\hline Q.26 & $\begin{array}{lll}\begin{array}{l}\text { Promotional actions } \\
\text { coupon) }\end{array} & \text { (discount } \\
\end{array}$ & .50 & Reasonable & 519 \\
\hline Q.8 & Availability of products in stock & .49 & Reasonable & 307 \\
\hline Q.27 & Ease of registration on website & .48 & Reasonable & 475 \\
\hline Q.3 & Reliability on delivery & .46 & Reasonable & 522 \\
\hline Q.22 & $\begin{array}{l}\text { Trial tools/test online (illustrative } \\
\text { photos and explanatory videos) }\end{array}$ & .45 & Reasonable & 297 \\
\hline Q.31 & $\begin{array}{l}\text { Opinion research (on the product } \\
\text { purchased, the website, the new } \\
\text { products, and others.) }\end{array}$ & .45 & Reasonable & 460 \\
\hline Q.29 & $\begin{array}{l}\text { Customizing the site (personal } \\
\text { pages on banking sites, link to } \\
\text { history of purchasing, indication } \\
\text { of products according the profile } \\
\text { of purchasing, and others.) }\end{array}$ & .45 & Reasonable & 405 \\
\hline \multicolumn{4}{|c|}{ Reliability ( $\alpha$ de Cronbach) } & 88 \\
\hline & ariance explained & & & $26.4 \%$ \\
\hline
\end{tabular}

Source: Data from this research (2017).

Finally, we proceeded to the parallel analysis, consisting in comparing the eigenvalue estimated with the empirical value obtained through Rainegen software, since it is considered one of the most accurate methods for determining the number of factors (Hayton; Allen and Scarpello, 2004). This analysis showed 2 factors. Therefore, solutions to 2:03 factors were analyzed, but the strong correlation between them $(r>.6)$ signaled the existence of a secondorder factor, finally pointing to a one-factor solution as the most suitable for ecommerce rating scale.

The analysis was then performed as major axis with minimal load 0.45 (TABACHNICK; FIDELL,2013) to assure items with higher quality and oblique Promax rotation. The optimal solution appeared after 4 interactions. The final 
version included 21 items. According to Pasquali (2010), a construct can be well represented with 20 items.

Then we proceeded to the analysis of psychometric indices of the scale, which are explained by percentage of variance, validity/quality and reliability/accuracy. The percentage of variance explained was $26.4 \%$ of the total variance of the construct "evaluation of e-commerce."

The scale validity or quality of the items is checked by means of factorial loadings of each item, or items with correlation of the factor to which they belong. Comrey (1973) states that the quality of the scale items can be classified according their factor loadings. As the same author: excellent (highest to 0.71), very good (greater than or equal to 0.63 ), good (greater than or equal to 0.55 ), reasonable (greater than or equal to 0.45 ) and poor (most or equal to 0.32 ). The rating scale of e-commerce consists of 1 very good item, 8 good items and 12 reasonable items. Finally, the reliability of the scale was measured by Cronbach's alpha. According to Nunnally and Bernstein (1994), for exploratory studies, above 0.70 indicate that the scale values is reliable and values above 0.8 indicate that the instrument is very reliable. The Cronbach's alpha obtained for this instrument was 0.88 , considered very reliable. The Table 1summarizes psychometric indices of the e-commerce rating scale.

Finally, from the validated scale and factor scores calculated subsequently, it was possible to describe the perception of respondents on e-commerce shopping experience and the logistics activities of the sites that they usedto purchase.A rating scale of e-commerce told 21 questions or items that analyzed the degree of importance of each item to the shopping experience and logistics activities involved in online shopping. The items were assessed using a Likert scale of five points, where the number 1 represented "unimportant" and 5 "very important" and 3 was the neutral "does not apply/indifferent."

In relation to the total answers, most respondents (60.6\%) showed values 4 and 5 , indicating the relevance of the items for a profitable e-commerce, against $17.8 \%$ of answers 1 and 2 . Several items of the rating scale had high values for average and mode, which confirms the high degree of importance of logistics activities as a good shopping experience for success of e-commerce (BALLOU, 2006; QIAN, 2016).

Specifically, there is an item (A.17), which measures the safety of the site as the client's bank details. On the other hand, the item worst rated was the sustainability actions (Q.19), revealing that the customers from Brasilia, Brazil still do not consider social and environmental responsibility of companies in their purchasing decisions.

The results are summarized in descending order of average in Table 2.

Table 2- Assessment of the rating scale by the sample of research

\begin{tabular}{llcccc}
\hline \multicolumn{1}{c}{ Item } & \multicolumn{1}{c}{ Variable } & Average & \multicolumn{2}{c}{$\begin{array}{c}\text { Standard } \\
\text { deviation }\end{array}$} & Mode \\
\hline Q.17 & $\begin{array}{l}\text { Site security related to bank } \\
\text { details }\end{array}$ & 4.70 & 0.77 & 5 \\
\hline Q.3 & Reliability on delivery & & 4.68 & 0.64 & 5 \\
\hline
\end{tabular}


Site security related to personal

information of customer (guarantee that the data will not

4.57

$0.77 \quad 5$ be used by third parties)

\begin{tabular}{|c|c|c|c|c|}
\hline Q.23 & $\begin{array}{l}\text { Ability to track /monitor the } \\
\text { status of the order }\end{array}$ & 4.31 & 0.86 & 5 \\
\hline Q.10 & User-friendliness on website & 4.25 & 0.78 & 5 \\
\hline Q.27 & Ease of registration on website & 4.13 & 0.93 & 5 \\
\hline Q.8 & Availability of products in stock & 3.99 & 0.88 & 4 \\
\hline Q.30 & Ease of cancel the order & 3.92 & 1.17 & 5 \\
\hline Q.9 & $\begin{array}{l}\text { Online communication tools for } \\
\text { questions, complaints and } \\
\text { suggestions }\end{array}$ & 3.76 & 1.17 & 5 \\
\hline Q.28 & $\begin{array}{l}\text { Ease of cancel the registration on } \\
\text { the website }\end{array}$ & 3.70 & 1.18 & 5 \\
\hline Q.20 & $\begin{array}{l}\text { Reliability/quality of the raw } \\
\text { material of the product }\end{array}$ & 3.61 & 1.15 & 3 \\
\hline Q.6 & $\begin{array}{l}\text { Clarity on product return } \\
\text { procedures }\end{array}$ & 3.56 & 1.19 & 4 \\
\hline Q.22 & $\begin{array}{l}\text { Trial tools/test online (illustrative } \\
\text { photos and explanatory videos) }\end{array}$ & 3.55 & 1.13 & 4 \\
\hline Q.26 & $\begin{array}{l}\text { Promotional actions (discount } \\
\text { coupon) }\end{array}$ & 3.41 & 1.20 & 3 \\
\hline Q.13 & $\begin{array}{l}\text { Prices comparison tool with } \\
\text { competing products or physical } \\
\text { stores }\end{array}$ & 3.33 & 1.17 & 4 \\
\hline Q.18 & $\begin{array}{l}\text { Product compliance with quality } \\
\text { and safety standards (quality } \\
\text { standards, minimum age for toys) }\end{array}$ & 3.30 & 1.31 & 3 \\
\hline Q.29 & $\begin{array}{l}\text { Customizing the site (personal } \\
\text { pages on banking sites, link to } \\
\text { history of purchasing, indication } \\
\text { of products according the profile } \\
\text { of purchasing, and others.) }\end{array}$ & 3.25 & 1.16 & 3 \\
\hline Q.31 & $\begin{array}{l}\text { Opinion research (on the product } \\
\text { purchased, the website, the new } \\
\text { products, and others.) }\end{array}$ & 3.10 & 1.22 & 3 \\
\hline Q.25 & Loyaltyprograms/frequency & 3.02 & 1.27 & 3 \\
\hline Q.7 & $\begin{array}{l}\text { Clarity in discard procedures } \\
\text { after use of products and } \\
\text { materials, when necessary }\end{array}$ & 2.66 & 113 & 3 \\
\hline Q.19 & $\begin{array}{l}\text { Company with sustainability } \\
\text { actions (environmental and social } \\
\text { programs) }\end{array}$ & 2.59 & 1.20 & 3 \\
\hline
\end{tabular}

Source: Data from this research (2017). 


\section{DISCUSSION}

The mentioned literature, in section 2.4, highlights the common trends in ecommerce, considering logistics aspects. However, there is a lack of papers developing and validating, scientifically, a scale to measure consumer perceptions of their online shopping considering aspects related to logistics service level, as also stated by Qian (2016). For such a reason, in the present paper an empirical analysis is carried out in order to fill this literature gap.

This model highlights some theoretical and practical implications associated with the perceptions related to logistics service level in online shopping. The rating scale of e-commerce related to logistics aspects aid managers to design strategies and to take decisions that prioritize the fundamental logistics activities in e-commerce and optimize the shopping experience and customer postpurchase order, as emphasized by Ramanathan (2010).

The categorical thematic analysis performed indicated the existence of two categories: logistics systems and shopping experience, confirming the relevance of these factors for e-commerce, as suggested in the literature visited. The factors included in the logistics systems and presented in the assessment scale validated corroborate the quality indicators of logistics in e-commerce cited by Qian (2016). The factors include order response, answer response rate, delivery time, error processing and economy related to costs of logistics. In our research, a strong importance was given to the safety of the site concerning the client's bank details. Otherwise, low importance to environmental aspects in logistics service, for instance, the issues related to return of the product by reverse logistics

In general, it was perceived that people in the sample confirmed the relevance of the logistics service level, as well as the shopping experience and after-purchase on the websites. In addition, the results corroborate the studies of Burma (2015) and of Giuffrida et al. (2016), what emphasize the positive relation between logistic structure and e-commerce and the importance of the logistic performance index to measure the quality of logistics service in ecommerce. Thus, managers of ecommerce need to pay attention to these factors in order to increase their marketing and logistics strategies in their eagerness to get better reviews and customers more satisfied and loyal. It should be noted that the average or overall factor score, considering all the items of the scale for this research was 3.67. Thus, considering the maximum point in the range 5 , there is much room for e-commerce companies to work aspects in order to provide greater value to its customers and become more competitive, meeting the statement of Han and Wang (2017). The authors conclude that there are conditions and opportunities for the development of the e-commerce, however there are still several bottlenecks for the development of logistics. 


\section{CONCLUDING REMARKS}

It is clear the relevance and the growth of electronic commerce in the current business scenario, which requires of the companies operating in it strategies and different approaches to achieve the goals proposed. However, it was not found in the scientific literature studies presenting measures validated scientifically to evaluate e-commerce. Thus, the academic contribution of this research lies in the development and validation of the rating scale of ecommerce, considering the logistics service level, which presented good psychometric indexes that can be used in relational academic studies in the areas of Marketing and Logistics.

Furthermore, given that the administration is essentially applied science, the results for now obtained constitute a preliminary diagnosis that can support managers of electronic commerce and virtual enterprises in general. The rating scale of e-commerce related to logistics aspects aid managers to design strategies and to take decisions that prioritize the fundamental logistics activities in ecommerce and optimize the shopping experience and customer post-purchase order. Thus, achieving the loyalty of customers related to logistics service level in online purchasing, it can be translated into more sustainable and better results in a competitive scenario.

As for limitations, the proposal presented here it is a first attempt to build and validate a measure to evaluate the e-commerce on the logistics service level and the shopping experience. Therefore, the results are more indicative than conclusive. It should be emphasized that the sample was non-probabilistic, not allowing any generalization, make pressing new validations for the scale. Thus, it is recommended to carry out further studies with different profiles of samples, including other regions of Brazil for a broader conceptual framework related to the evaluation of e-commerce considering logistics activities.

Another limitation is that because of the cross-sectional nature of the data, questions regarding causality remain unanswered. Accordingly, the development of a time series data base allows the test structure for the time being obtained in a longitudinal perspective, which will provide an important refinement of the scale. Thus, there may be the need of modification, addition or deletion of some of the original items of the sort of scale in order to achieve a reliable measure of evaluation of e-commerce. Additionally, it can be built in a continuous and current way based on new trends on marketing and logistics concepts.

Finally, the analysis of the empirical literature regarding the logistics in ecommerce showed a meager production, resulting in a call for more research on the subject. It is needed more multi-method nature, covering both qualitative and quantitative approaches to provide, beyond the measurement, a better understanding of the phenomenon under study. Also, it is needed studies focusing in validations of scales and the consideration of the public sector and the third sector as a place of research. It is also suggested further studies that address issues related to logistics and environmental responsibility. Considering the increasing demands on management practices related to this topic, which also leads to research directed to logistics reverse. It should be highlighted that this aspect was considered of little relevance to respondents. 
Despite the limitations presented, this study achieved its goal to present a seminal proposal of scientifically validated tool for evaluating e-commerce, considering aspects related to logistics service level. The rating scale of ecommerce presented validity and reliability, which allows its use in relational diagnostic and scientific research. Since then, new studies and validations should be undertaken to enhance the scale and contribute to the progressive advancement of theoretical and empirical knowledge about logistics and shopping experience in the online environment. 


\section{Análise da relação entre nível de serviço logístico e experiência de compra no e- commerce brasileiro: Uma escala de avaliação}

\section{RESUMO}

O desempenho da logística torna-se ainda mais relevante no comércio eletrônico, exigindo das empresas alta especialização. Considerando a falta de instrumentos na literatura para avaliar o sistema logístico relacionado à experiência de compras on-line, o objetivo desta pesquisa, de natureza quantitativa, foi desenvolver e validar uma escala de avaliação do e-commerce. Os resultados forneceram um diagnóstico preliminar que pode auxiliar os gestores do e-commerce a tomar melhores decisões em termos de nível de serviço logístico, as quais normalmente envolvem custos elevados e nem sempre são percebidas pelos clientes. Além disso, a escala de avaliação do e-commerce, considerando aspectos logísticos, desenvolvida e validada nesta pesquisa, pode auxiliar os gestores a desenhar estratégias e a tomar decisões que otimizem as atividades logísticas e a experiência de compra no e-commerce.

PALAVRAS-CHAVE: E-commerce. Escala de avaliação. Experiências de compra online. Nível de serviço logístico. 


\section{REFERÊNCIAS}

ABComm - Associação Brasileira de Comércio Eletrônico. E-commerce brasileiro deve faturar R\$ 49,8 bilhões em 2015. Available at: http://www.abcomm.org/noticias/e-commerce-brasileiro-deve-faturar-r-498bilhoes-em-2015-preve-abcomm/Acessed in 03/15/2016.

ALDIN, N.; STAHRE, F. Electronic commerce, marketing channels and logistics platforms - a wholesaler perspective. European Journal of Operational Research, v. 144, p. 270-279, 2003.

BALLOU, R. H. Revenue estimation for logistics customer service offerings. The International Journal of Logistics Management, v. 17, n. 1, p. 21 - 37, 2006. crossref

BALLOU, R. H. Gerenciamento da Cadeia de Suprimentos: Logística Empresarial. (4.ed). São Paulo: Bookman, 2001.

BOWERSOX, D. J.; CLOSS, D.J.; COOPER, M. B. Gestão Logística de Cadeias de Suprimentos.São Paulo: Bookman, 2006.

BURMA, A. P. D. Z. A. How to Increase E-Commerce Incomes: A Correlation and a Cluster Analysis. Country Studies, v. 5, n. 4, p. 65-84, 2015

CHING, H. Y. Gestão de Estoques na Cadeia de Logística Integrada. (4.ed). São Paulo: Atlas, 2010.

CHO, J. J.-K.; OZMENT, J.; SINK, H. Logistics capability, logistics outsourcing and firm performance in an e-commerce market. International Journal of Physical Distribution and Logistics Management, v. 38, n. 5, p. 336-359, 2008. crossref

CHOPRA, S.; MEINDL, P.Supply chain management. Strategy, planning \& operation. Gabler: Pearson, 2007.

CHRISTOPHER, M.Logistics \&Suply Chain Management.(4.ed). São Paulo: Pearson Prentice Hall, 2001.

COCHRAN, W. G. Sampling techniques. (3.ed). New York: John Wiley \& Sons, 2007.

COMREY, A. L.A first course in factor analysis. New York: Academic Press, 1973. 
COOPER, M.; ELLRAM, L. Characteristics of supply chainmanagement and theimplications for purchasing and logistics strategy. The International Journal of Logistics Management,v. 4, n. 2, p. 13-24, 1993. crossref

CSCMP - Council of Supply Chain Management Professionals (2010).Supply Chain Management: Terms and glossary, February, 2010. <http://cscmp.org/resourcesresearch/glossary-terms> Accessed in: 01/12/2016.

DE MARCO, A.; CAGLIANO, A. C.; MANGANO, G.; PERFETTI, F.Factor Influencing Logistics Service Providers Efficiency' in Urban Distribution Systems. Transportation Research Procedia,v. 3, July, p. 499-507, 2014. crossref

DEMO, G. B2C Market: Development of a CRM Scale. IN: GHORBANI, A. (Ed.). Marketing in the Cyber Era. Hershey, PA: IGI Global, pp. 85-95, 2014.

NEIVA, E.; NUNES, I.; ROZZETT, K.Human Resources Management Policies and Practices Scale (HRMPPS): Exploratory and Confirmatory Factor Analysis. Brazilian Administration Review, v. 9, n. 4, p. 395- 420, 2012. crossref

DORNIER, P.P.; ERNST, R.; FENDER, M.; KOUVELIS, P. Global Operations and Logistics: Text and Cases. New York: Wiley, 2007.

FIELD, A. (2009). Discovering statistics using SPSS.(3.ed.). Thousand Oaks, CA: Sage.

GIUfFRIDA, M.; MANGIARACINA, R.; PEREGO, A.; TUMINO, A.Logistics Solutions to Support Cross Border E-Commerce Towards China: The Case of the Apparel Industry. In:Workshop on Business Models and ICT Technologies for the Fashion Supply Chain (pp. 163-177). Springer, Cham, 2016.

GUARNIERI, P.; HATAKEYAMA, K. Formalização da logística de suprimentos: caso das montadoras e fornecedores da indústria automotiva brasileira. Production, $v$. 20, n. 2, p. 186-199, 2010. crossref

HAIR JR, J. F.; BABIN, B.; MONEY, A. H.; SAMOUEL, P.Fundamentos de métodos de pesquisa em administração. São Paulo: Artmed, 2005.

HAIR, J. F.; BLACK, W. C.; BABI, B. J.; ANDERSON, R. E.; TATHAM, R. L. Análise multivariada de dados. (6.ed.) Porto Alegre: Bookman, 2009. 
HAN, M.; WANG, H.Fourth International Forum on Decision Sciences.Study of Community E-commerce Logistic Distribution Model Based on Intelligent Community Property. Proceedings...Springer, Singapore, 2017.

HARRISON, A.; VAN HOEK, R.Logistics Management and Strategy. (1.ed.). FinancialTimes. London:Prentice-Hall, 2002.

HAYTON, J. C.; ALLEN, D. G.; SCARPELLO, V. Factor retention decisions in exploratory factor analysis: a tutorial on parallel analysis. Organizational Research Methods, v. 7, n. 2, p. 191-205, 2004. crossref

HEIM, G.R.; FIELD, J.M. Process drivers of e-service quality: analysis of data from an online rating site. Journal of Operations Management, v. 25, n. 5, p. 962-984, 2007.

HOFF, A.; ANDERSSON, H.; CHRISTIANSEN, M., HASLE, G.;LØKKETANGEN, A. Industrial aspects and literature survey: Fleet composition and routing. Computers \& Operations Research, v. 37, n. 12, p. 2041-2061, 2010. crossref

KAISER, H. F. An index of factorial simplicity. Psychometrika, v. 39, n. 1, p. 31-36, 1974. crossref

KERLINGER, F. N.; LEE, H. B.Foundations of behavioral research. (5.ed.) Independence, KY: Wadsworth Thomson, 2008.

KOTLER, P.; KELLER K.Marketing Management. (12.ed). New York: Prentice Hall, 2006.

LAMBERT, D.; COOPER, M.Issues in supply chainmanagement. Industrial Marketing Management, v. 29, p. 65-83, 2000. crossref

LANKFORD, W. M. Supply chain management and the Internet. Online Information Review, v. 28, n. 4, p. 301-305, 2004. crossref

LIN, L.; GEN, M. S.; WANG, X. G. Integrated multistage logistics network design by using hybrid evolutionary algorithm. Computers \& Industrial Engineering, v. 56, n. $3,854-873,2009$. crossref

MEIDUTĖ-KAVA LIAUSKIENĖ, I.; ARANSKIS, A.; LITVINENKO, M. Consumer Satisfaction with the Quality of Logistics Services. Procedia - Social and Behavioral Sciences, v. 110, p. 330-340, 2014. 
MEIRA JR, W.; MURTA, C. D; CAMPOS, S. V. A.; GUEDES NETO, D. O. Sistemas de Comércio Eletrônico: Projeto e Desenvolvimento. Rio de Janeiro: Campus, 2002.

MENARD, S. Applied logistic regression analysis. Thousand Oaks, CA: Sage, 2002. crossref

MESUT, S.; INCEKARA, A.; SENER, S. The Potential of E-Commerce for SMEs in a Globalizing Business Environment. Procedia - Social and Behavioral Sciences, v. 150, p. 35-45, 2014. crossref

MORGANTI, E; SEIDEL, S.; BLANQUART, C.; DABLANC, L.; LENZ, B. The impact of ecommerce on final deliveries: alternative parcel delivery services in France and Germany. Transportation Research Procedia, v. 4, p.178 - 190. In: Myers, R. (1990). Classical and modern regression with applications (2.ed.). Boston, MA: Duxbury, 2014. crossref

NOVAES, A. G. Logística e Gerenciamento da Cadeia de Distribuição: Estratégia, Operação e Avaliação. (3.ed.).Rio de Janeiro: Editora Campus, 2007.

NUNNALlY, J. C.; BERNSTEIN, I. H. Psychometrictheory. (3.ed.). New York: McGraw-Hill, 1994.

PASQUALI, L. Instrumentação psicológica: fundamentos e práticas. Porto Alegre: Artmed, 2010.

PASQUALI, L.Análise fatorial para pesquisadoresLaboratório de Pesquisa em Avaliação e Medida - LabPAM. Brasília: Universidade de Brasília (UniversityofBrasilia), 2012.

PIRES, S. R. I.Gestão da Cadeia de Suprimentos. São Paulo: Editora Atlas, 2004.

QIAN, L. I. Logistics Service Quality Evaluation for E-Commerce Based on Extenics Theory. International Journal of Simulation--Systems, Science \& Technology, v. 17, n. 2, p. 1-6, 2016.

RABINOVICH, E.; KNEMEYER, A.M. Logistics service providers in internet supply chains. California Management Review, v. 48, n. 4, p. 84-108, 2006. crossref

;MAYER, C. M. Why do Internet commerce firms incorporate logistics service providers in their distribution channels? The role of transaction costs and network strength. Journal of Operations Management, v. 25, p. 661681, 2007. crossref 
RAMANATHAN, R. The moderating roles of risk and efficiency on the relationship between logistics performance and customer loyalty in e-commerce. Transportation Research Part E, v. 46, n. 6, p. 950-962, 2010. crossref

RUTNER, S. M.; GIBSON, B. J.; WILLIAMS, S. R.The Impacts of the integrated logistics systems on electronic commerce and enterprise resource planning systems. Transportation Research Part E, v. 39, n. 2, p.83-93, 2003. crossref

SISODIA, R.; WOLFE, D. B.; SHETH, J. N. Firms of Endearment: How World-Class Companies Profit from Passion and Purpose. Upper Sadde River, NJ: Wharton School Publishing, 2007.

TABACHNICK, B. G.; FIDELL, L. S. Using multivariate statistics. (6.ed.). San Francisco: Allyn \& Bacon, 2013.

XIANGLIAN, C.; HUA, L. Research on E-Commerce Logistics System Informationization in Chain. Procedia - Social and Behavioral Sciences, v. 96 (Cictp), p. 838-843, 2013.

XU, S. X.; CHENG,M.; HUANG, G. Q. Efficient Intermodal Transportation Auctions for B2B E-Commerce Logistics with Transaction Costs. Transportation Research Part B: Methodological, v. 80, p. 322-337, 2015. crossref

YU, Y.; WANG, X.; ZHONG, R. Y.; HUANG, G. Q. E-commerce Logistics in Supply Chain Management: Practice Perspective. Procedia CIRP, v. 52, p. 179-185, 2016. crossref

ZHANG, M.; HUANG, G. Q.; XU, S. X.; ZHAO, Z. Optimization based transportation service trading in $\mathrm{B} 2 \mathrm{~B}$ e-commerce logistics. Journal of Intelligent Manufacturing, April, p.1-17, 2017.

Recebido: 01 dez. 2017

Aprovado: 12 dez. 2017

DOI: 10.3895/gi.v13n4.7455

Como citar:

DEMO, G.; GUARNIERI, P.; ALVARENGA, B. Analysis of the relation of logistics service level and the shopping experience in brazilian e-commerce: a rating scale. R. Gest. Industr., Ponta Grossa, v. 13, n. 4, p. 98-121, out./dez. 2017. Disponível em: $\leq$ https://periodicos.utfpr.edu.br/rgi>. Acesso em: XXX.

Correspondência:

Gisela Demo

Universidade de Brasília: Campus Universitário Darcy Ribeiro, prédio da FACE, sala AT 111/4. Asa NorteBrasília, Distrito Federal, Brasil.

Direito autoral: Este artigo está licenciado sob os termos da Licença Creative Commons-Atribuição 4.0

Internacional.

\section{(c) (i)}

